\title{
Spelling performance of public and private school students: A comparative study
}

\author{
Desempenho ortográfico de escolares do ensino particular e público: \\ estudo de caracterização e relação
}

\author{
Maria Nobre SAMPAIO' \\ Natália FUSCO ${ }^{1}$ \\ Ana Carla Leite ROMERO ${ }^{2}$ \\ Amanda Corrêa do AMARAL ${ }^{3}$ \\ Simone Aparecida CAPELLINI ${ }^{1}$
}

\begin{abstract}
To characterize and compare the spelling performance of private and public students. Three hundred 1st-5th graders from public and private schools in the city of Marilia, São Paulo, Brazil, were evaluated, totalizing 30 students from each grade, respectively. Collective and individual versions of the Pró-Ortografia test (a renowned Brazilian spelling test) were administered. There were significant inter-group differences indicating that private school students achieved higher performance. The mean values of correct answers of higher grade level students were statistically greater than those of the lower grade level students. The results indicated that the mean values of correct answers of all versions of the spelling test administered increased across grades for both private and public school students. However, the data evaluated showed that private school students attained higher spelling performance than public school students from the 2 nd grade onwards.
\end{abstract}

Keywords: Evaluation; Handwriting; Learning; Teaching.

\section{Resumo}

O estudo buscou caracterizar e relacionar o desempenho ortográfico dos escolares de $1^{\circ}$ ao $5^{\circ}$ ano do ensino particular e público. Foram avaliados 300 escolares do $1^{\circ}$ ao $5^{\circ}$ ano em duas escolas, uma particular e outra pública, da cidade de Marília, São Paulo, sendo 30 alunos de cada ano escolar. Como procedimento, foi aplicado o Pró-Ortografia na sua versão coletiva e individual. Houve diferença estatisticamente significativa na comparação intergrupos, indicando desempenho

\footnotetext{
1 Universidade Estadual Paulista "Júlio de Mesquita Filho", Faculdade de Filosofia e Ciências, Programa de Pós-Graduação em Educação. Av. Hygino Muzzi Filho, 737, Mirante, 17525-000, Marília, SP, Brasil. Correspondência para/Correspondence to: M.N. SAMPAIO. E-mail: <marianobre.unesp@gmail.com>.

2 Universidade Estadual Paulista "Júlio de Mesquita Filho", Faculdade de Filosofia e Ciências, Programa de Pós-Graduação em Fonoaudiologia. Marília, SP, Brasil.

${ }^{3}$ Universidade Estadual Paulista "Júlio de Mesquita Filho", Faculdade de Filosofia e Ciências, Departamento de Fonoaudiologia. Marília, SP, Brasil.

Support: Fundação de Amparo à Pesquisa do Estado de São Paulo.
} 
superior dos escolares do ensino particular. Com o aumento da seriação, todos os grupos aumentaram a média de acertos nas provas avaliadas. Os resultados indicaram que as médias de acertos nas provas ortográficas se tornaram superiores com a progressão escolar tanto para os escolares do ensino particular quanto para os do ensino público. No entanto, os dados evidenciaram que os alunos do ensino particular apresentaram desempenho ortográfico superior em relação aos do ensino público a partir do $2^{\circ}$ ano.

Palavras-chave: Avaliação; Escrita manual; Aprendizagem; Ensino.

The acquisition of written language enables students to integrate and participate in social practices. Writing requires different linguistic and cognitive skills related to a writing system. Thus, the metalinguistic skills, which correspond to explicit manifestations of a functional awareness of the rules of the organization or use of language, as well as the ability to think and consciously manipulate the linguistic knowledge, are essential to the formal learning-to-write process in schools (Lima \& Pessoa, 2007). Therefore, both the phonological and the spelling processes are important to the process of writing acquisition (Mousinho \& Correa, 2009; Paschoal, Pezarini, Vaz, \& Chacon, 2014; Smythe et al., 2008).

Thus, the basis for understanding an alphabetic writing system, such as the Brazilian Portuguese, is grasping the concept that written words are made up of units smaller than a syllable, which are responsible for the meaning of the word, and that these smaller units can be represented by graphic signs (Guimarães, Paula, Mota, \& Barbosa, 2014; Moraes, 2008).

According to Gindri, Keske-Soares, and Mota (2005), in order for children to understand the alphabetic principle of graphophonemic correspondence, they need to understand that the letters correspond to sound segments that have no inherent meaning. Written language is therefore closely related to the oral language. Although it is relatively easy for most children to learn to read and write, there are several and complex basic language and cognitive skills necessary for learning.

In the writing process, a spelling activity starts with the decision on the concept about which the writer wants to write, using primarily his or her semantic system. Next, the syntactic structure will determine the type of words to be used in a sentence, and only then are the phonological route and lexical or orthographic routes used, enabling writing the words. After the mental orthographic representation of the word, there are two subprocesses that are necessary for the actual writing. The first one is related to the selection mechanism of the graphemes and the style and size of the font to be used (uppercase, lowercase). The second process is related to the execution of the necessary motor movements for each phoneme (Manzano, Sanz, \& Chocano, 2008).

The Portuguese writing system is characterized by Orthographic Transparency and the Orthographic Opacity. The transparent relationship between phonology and orthography in the Portuguese language seems to make reading easy but spelling difficult. Therefore, it can be said that Brazilian Portuguese has a higher degree of grapheme-phoneme correspondence than that of phoneme-grapheme (Mousinho \& Correa, 2009). Thus, the assessment of spelling can indicate the student's level of competence, helping the teacher or professional working with the student to choose intervention strategies for each specific difficulty (Cérvera-Mérida \& Ygual-Fernández, 2006).

However, the role of the school in selecting the teaching method has a direct influence on the cognitive skills needed to achieve literacy (Kleiman, 2001). Due to the great diversity of sociocultural environments and a limited conceptual understanding of the reading and writing acquisition process, the teaching approaches used in Brazilian schools are often not related to the way students learn (Salles, Parente, \& Freitas, 2010). Therefore, understanding how the spelling acquisition process takes place and determining whether there are differences between public and private education 
can contribute to the use of intervention and educational strategies.

Accordingly, the hypothesis of this study is based on the fact that regardless of the type of education, there will not be differences in the acquisition of Portuguese spelling since the rules of encoding words are not explicitly taught in these two types of school. Thus, the objective of the present study is to characterize and compare the spelling performance of 1st-5th grade private and public school students.

\section{Method}

This study was approved by the Research Ethics Committee of the Universidade Estadual Paulista "Júlio de Mesquita Filho" (São Paulo State University) Protocol n 428/2009.

\section{Participants}

A total of 300 private and public 1st-5th grade school students participated in this study; 150 students attending private schools and 150 attending public schools in the city of Marilia (SP), Brazil. The age of the participants ranged from 7 to 11 years 11 months. Among the private schools students, $46 \%$ were female and $54 \%$ male, and among the public school students, $49 \%$ were female and $51 \%$ were male. However, the students were not paired according to gender since the focus of the study was the performance of 1st-5th graders in general.

The 150 private school students were divided into five groups of 30 1st-5th graders: Gl, GIl, GIII, GIV, and GV, respectively. Similarly, the 150 public school students were divided into five groups of 30 1st-5th graders: GVI, GVII, GVIII, GIX, and GX, respectively.

The exclusion criteria were as follows: sensory, motor, or cognitive disabilities and nonsubmission of Informed Consent signed by parents or guardians. The Inclusion criteria were: submission of Informed Consent signed by parents or guardians and no hearing or visual impairments according to the school records.

\section{Instruments}

The Protocolo de Avaliação da Ortografia - Pró-Ortografia (Spelling Assessment Protocol), a renowned Brazilian spelling test, was used (Batista Cervera-Mérida, Ygual-Fernández, \& Capellini, 2014) because it includes several different tests that enable a thorough analysis of the students' performance.

This instrument consists of collective and individual versions, as described below:

\section{Collective version}

- Escrita das Letras do Alfabeto (ELA, Alphabet Letter Writing): the students were instructed to write the letters of the alphabet, the vowels, and the consonants separately to verify their knowledge of them, as well as their classification. One point was given for each correctly sequenced letter.

- Ditado Randomizado das Letras do Alfabeto (DRLA, Randomized Dictation of Alphabet Letters): the students were instructed to write the letters dictated to verify their knowledge of the letter names and their shape. One point was given for each letter written in the same order they were dictated.

- Ditado de Palavras (DP, Word Dictation): the students were instructed to write 86 words dictated to verify their level of knowledge of rules of encoding words under the control of the dictated material and with the support of visual input lexicon. One point was given for each correctly written word, including the correct use of Portuguese accents.

- Ditado de Pseudopalavras (DPP, Pseudoword Dictation): the students were instructed to write 36 pseudowords dictated to verify their level of knowledge of rules of encoding words according to the psycholinguistic criterion of semantic regularity, 
following orthographic regularities and rules, under the control of the dictated material, without the support of visual input lexicon. One point was given for each correctly written pseudoword, including the correct use of Portuguese accents.

- Ditado com Figuras (DF, Dictation with Picture (ards): the students were instructed to write 39 words corresponding to each picture card shown to verify their level of knowledge of rules of encoding words by a phonological representation in the mental lexicon. All picture cards belonged to the same semantic category. One point was given for each correctly written word corresponding to the pictures cards, including the correct use of Portuguese accents.

\section{Individual version}

- Ditado de Frases (DFR, Sentence Dictation): the students were instructed to write 12 sentences dictated, totaling 66 words to investigate whether there is an association (or influence) between memory and writing skills these sentences were also used in the deliberate spelling mistake test. One point was given for each correctly written word, including the correct use of Portuguese accents.

- Erro Proposital (EP, Deliberate Misspelling): the students were instructed to rewrite the 12 previously dictated sentences, but with intentional misspellings to verify their knowledge of some forms of semantic regularity through the verbal representation of their deliberate misspellings. One point was given for each word intentionally spelled wrong with adequate justification for its purposeful misspelling.

- Ditado Soletrado (DS, Dictation by spelling every letter in every word): the students were instructed to write 29 words dictated by slowly spelling every letter in every word to verify their ability to form a word from the letters provided following the sequence dictated and using visual input lexicon. One point was given for each correctly written word.

- Memória Lexical Ortográfica (MLO, Lexical to write 29 words as requested to verify their ability to retrieve from orthographic lexicon when using phonological working memory (for example: "write a word that contains the letters "GE" together at the beginning or in the middle of the word - 'get', 'angel'"). One point was given for each correctly written word corresponding to the letters provided, including the correct use of Portuguese accents.

This assessment instrument was created following the steps used to develop this type of instrument, which included design, application, correction, and interpretation of the results based on psycholinguistics. The steps of content validity, criterion validity, and construct validity are still under analysis.

Data collection was performed after approval by the school board. Firstly, the collective version of the instrument was administered by the researcher in the school during class hours in the presence of the classroom teacher. It took about 50 minutes, and it was administered in two sessions. The individual version was also administered in the school during class hours, took about 40 minutes, and was also administered in two sessions.

Since the number of correct answers could vary according to the different tests used in the present study, nonparametric statistics was used. The Statistical Package for the Social Sciences (SPSS) version 17.0, was used based on the number of correct answers given by the ten groups formed comparing the performance of the students in terms of their knowledge of spelling rules. The results were analyzed using the Bonferronicorrected Mann-Whitney $U$ test and Spearman correlation at a significance level of 5\% (0.050), as denoted by an asterisk in Tables 1-5.

\section{Results}

Table 1 shows the mean values of the correct answers, standard deviation, and p-value of the results of the spelling assessment test comparing 
the performance of the groups $\mathrm{Gl}$ and $\mathrm{GVI}$ and that of the groups GII and GVII.

As can be seen from Table 1, according to the Mann-Whitney $U$ test, there was a statistically significant difference only in the test dictation by spelling every letter in every word (DS), indicating that 1st graders from private school achieved higher performance than 1st graders from public school. It can be also observed that in the majority of the tests administered, the mean value of correct answers was higher for the 1st graders from private school, except for the tests pseudoword dictation (DPP) and deliberate misspelling (EP). Therefore, in the majority of tests, the mean values were higher for the group $\mathrm{Gl}$ than for the group $\mathrm{GVI}$, except for the two above-mentioned tests. A statistically significant difference between these two groups was found in one test only, indicating that GI and GVI students demonstrated similar knowledge of spelling and rules of the Brazilian Portuguese language in all versions of the test administered in this study.

Table 1

Mean, standard deviation, and p-value of the performance of groups GI and GVI and the groups GII and GVII in the spelling assessment test

\begin{tabular}{|c|c|c|c|c|c|c|c|c|}
\hline Variable & Group & Mean & $S D$ & Significance $(p)$ & Group & Mean & $S D$ & Significance $(p)$ \\
\hline \multirow[t]{2}{*}{ ELA } & I & 16.03 & 10.50 & \multirow{2}{*}{0.210} & II & 18.97 & 9.39 & \multirow{2}{*}{$0.032 *$} \\
\hline & $\mathrm{VI}$ & 13.90 & 10.06 & & VII & 11.77 & 9.55 & \\
\hline \multirow[t]{2}{*}{ DRLA } & I & 24.24 & 5.06 & \multirow{2}{*}{0.165} & $\|$ & 25.10 & 1.09 & \multirow{2}{*}{$0.015^{*}$} \\
\hline & $\mathrm{VI}$ & 22.50 & 2.44 & & VII & 23.07 & 4.67 & \\
\hline \multirow[t]{2}{*}{ DP } & I & 9.34 & 9.41 & \multirow{2}{*}{0.437} & $\|$ & 23.27 & 8.45 & \multirow{2}{*}{$<0.001 *$} \\
\hline & $\mathrm{VI}$ & 7.50 & 10.27 & & VII & 11.53 & 13.16 & \\
\hline \multirow[t]{2}{*}{ DPP } & 1 & 3.83 & 6.22 & \multirow{2}{*}{0.431} & ॥ & 8.70 & 3.62 & \multirow{2}{*}{$<0.001 *$} \\
\hline & $\mathrm{VI}$ & 4.63 & 3.07 & & VII & 2.57 & 2.86 & \\
\hline \multirow[t]{2}{*}{ DF } & I & 11.79 & 8.48 & \multirow{2}{*}{0.102} & $\|$ & 23.50 & 6.88 & \multirow{2}{*}{$<0.001 *$} \\
\hline & $\mathrm{VI}$ & 8.67 & 8.06 & & VII & 12.07 & 9.56 & \\
\hline \multirow[t]{2}{*}{ DRF } & I & 13.14 & 11.43 & \multirow{2}{*}{0.112} & $\|$ & 37.70 & 13.40 & \multirow{2}{*}{$<0.001 *$} \\
\hline & $\mathrm{VI}$ & 7.50 & 14.93 & & VII & 17.37 & 18.55 & \\
\hline \multirow[t]{2}{*}{ EP } & 1 & 0.00 & 0.00 & \multirow{2}{*}{$>0.999$} & ॥ & 0.97 & 2.08 & \multirow{2}{*}{$<0.001 *$} \\
\hline & $\mathrm{VI}$ & 0.00 & 0.00 & & VII & 0.00 & 0.00 & \\
\hline \multirow[t]{2}{*}{ DS } & 1 & 13.79 & 7.31 & \multirow{2}{*}{$0.011 *$} & $\|$ & 18.50 & 5.04 & \multirow{2}{*}{$0.001 *$} \\
\hline & $\mathrm{VI}$ & 8.77 & 6.32 & & VII & 12.83 & 6.79 & \\
\hline \multirow[t]{2}{*}{ MLO } & 1 & 6.52 & 5.09 & \multirow{2}{*}{0.951} & $\|$ & 14.87 & 4.66 & \multirow{2}{*}{$<0.001 *$} \\
\hline & $\mathrm{VI}$ & 6.30 & 5.37 & & VII & 7.93 & 7.45 & \\
\hline
\end{tabular}

Note: Numbers with an asterisk: statistically significant results.

ELA: Alphabet Letter Writing (Escrita de Letras do Alfabeto); DRLA: Randomized Dictation of Alphabet Letters (Ditado Randomizado de Letras do Alfabeto); DP: Word Ditaction (Ditado de Palavras); DPP: Pseudoword Ditaction (Ditado de Pseudopalavras); DF: Ditaction With Picture Cards (Ditado com Figuras); DFR: Sentence Ditaction (Ditado de Frases); EP: Deliberate Misspelling (Escrita por Erro Proposital); DS: Spelled Ditaction (Ditado Soletrado); MLO: Lexical Orthographic Retrieval (Escrita de Palavras por Memória Lexical Ortográfica); SD: Standard Deviation; GI: 1st graders from private school; Gll: 2nd graders from private school; GVI: 1st graders from public school; GVII: 2nd graders from public school; Statistical Analysis: Mann-Whitney U test.

Table 1 also shows a performance comparison between the groups GII and GVII. There was a statistically significant difference in all tests administered, indicating that 2 nd graders from private school achieved higher performance than 2nd graders from public school.

Table 2 shows the mean values of the correct answers, standard deviation, and p-value of the results of the spelling assessment test comparing the performance of the groups GIII and GVIII and that of the groups GIV and GIX.

It can be also seen from this Table that there was a statistically significant difference in the group GIII in the following tests: word dictation (DP), pseudoword dictation (DPP), dictation with picture cards (DF), sentence dictation (DRF), deliberate misspelling (EP), and dictation by spelling every letter in every word (DS), indicating that 3rd graders 
from private school achieved higher performance than 3rd graders from public school. On the other hand, although the mean value of correct answers of the group GIII were higher than those of the group GVI in all versions of the test administered, there were no statistically significant results between the groups in the tests alphabet letter writing (ELA), randomized dictation of alphabet letters (DRLA), and lexical orthographic retrieval (MLO).

As for the performance comparison between the groups GIV and GIX, this Table shows a statistically significant difference in all versions of the test administered, indicating that 4 th graders from private school achieved higher performance than 4th graders from public school.

Table 2

Mean, standard deviation, and p-value of the performance of groups GIII and GVIII; and GIV and GIX in the spelling assessment test

\begin{tabular}{|c|c|c|c|c|c|c|c|c|}
\hline Variable & Group & Mean & $S D$ & Significance $(p)$ & Group & Mean & $S D$ & Significance $(p)$ \\
\hline \multirow[t]{2}{*}{ ELA } & III & 24.17 & 4.01 & \multirow{2}{*}{0.133} & IV & 25.47 & 01.80 & \multirow{2}{*}{$0.032 *$} \\
\hline & VIII & 20.50 & 9.27 & & IX & 18.13 & 09.18 & \\
\hline \multirow[t]{2}{*}{ DRLA } & III & 23.90 & 4.37 & \multirow{2}{*}{0.649} & IV & 25.80 & 00.55 & \multirow{2}{*}{$0.015^{*}$} \\
\hline & VIII & 22.50 & 6.40 & & IX & 23.40 & 05.21 & \\
\hline \multirow[t]{2}{*}{ DP } & III & 46.77 & 14.92 & \multirow{2}{*}{$<0.001^{*}$} & IV & 54.67 & 13.53 & \multirow{2}{*}{$<0.001 *$} \\
\hline & VIII & 31.67 & 13.62 & & IX & 31.30 & 16.99 & \\
\hline \multirow[t]{2}{*}{ DPP } & III & 14.37 & 4.34 & \multirow{2}{*}{$<0.001^{*}$} & IV & 17.50 & 04.37 & \multirow{2}{*}{$<0.001 *$} \\
\hline & VIIII & 6.37 & 3.87 & & IX & 06.77 & 03.61 & \\
\hline \multirow[t]{2}{*}{ DF } & III & 28.07 & 5.55 & \multirow{2}{*}{$<0.001^{*}$} & IV & 30.00 & 04.33 & \multirow{2}{*}{$<0.001 *$} \\
\hline & VIII & 21.20 & 7.55 & & IX & 18.80 & 07.06 & \\
\hline \multirow[t]{2}{*}{ DRF } & III & 52.13 & 10.84 & \multirow{2}{*}{$0.033^{*}$} & IV & 55.23 & 09.54 & \multirow{2}{*}{$<0.001 *$} \\
\hline & VIIII & 41.13 & 19.84 & & IX & 38.37 & 18.30 & \\
\hline \multirow[t]{2}{*}{ EP } & III & 00.47 & 00.68 & \multirow{2}{*}{$0.001 *$} & IV & 02.60 & 03.04 & \multirow{2}{*}{$<0.001 *$} \\
\hline & VIII & 00.03 & 00.18 & & IX & 00.10 & 00.31 & \\
\hline \multirow[t]{2}{*}{ DS } & III & 21.60 & 5.78 & \multirow{2}{*}{$0.003^{*}$} & IV & 24.20 & 03.57 & \multirow{2}{*}{$0.001 *$} \\
\hline & VIII & 17.03 & 6.55 & & IX & 13.47 & 05.49 & \\
\hline \multirow[t]{2}{*}{ MLO } & III & 17.97 & 4.57 & \multirow{2}{*}{0.230} & IV & 21.27 & 04.53 & \multirow{2}{*}{$<0.001 *$} \\
\hline & VIII & 15.97 & 6.28 & & IX & 13.17 & 05.95 & \\
\hline
\end{tabular}

Note: Numbers with an asterisk: statistically significant results.

ELA: Alphabet Letter Writing (Escrita de Letras do Alfabeto); DRLA: Randomized Dictation of Alphabet Letters (Ditado Randomizado de Letras do Alfabeto); DP: Word Ditaction (Ditado de Palavras); DPP: Pseudoword Ditaction (Ditado de Pseudopalavras); DF: Ditaction With Picture Cards (Ditado com Figuras); DFR: Sentence Ditaction (Ditado de Frases); EP: Deliberate Misspelling (Escrita por Erro Proposital); DS: Spelled Ditaction (Ditado Soletrado); MLO: Lexical Orthographic Retrieval (Escrita de Palavras por Memória Lexical Ortográfica); SD: Standard Deviation; GI: 1st graders from private school; Gll: 2nd graders from private school; GVI: 1st graders from public school; GVII: 2nd graders from public school; Statistical Analysis: Mann-Whitney U test.

Table 3 shows the shows the mean values of the correct answers, standard deviation, and $p$-value of the results of the spelling assessment test comparing the performance of the groups GV and GX.

With regard to the performance of these two groups, this Table shows that there was a statistically significant difference in the majority of the tests administered, except for the tests alphabet letter writing (ELA) and randomized dictation of alphabet letters (DRLA), indicating that 5 th graders from private school achieved higher performance than 5 th graders from public school.
According to the data from Tables 1, 2, and 3, the mean values of correct answers of each test gradually increased at each higher grade level from 1st through 5th grade. In the private schools evaluated, there was a gradual increase in the mean values of correct answers for the groups GI-GV in the majority of the tests administered, except for the tests randomized dictation of alphabet letters (DRLA) and deliberate misspelling (EP), in which the mean values of correct answers of the groups GIII and GV were lower than those of the groups GII and GIV, respectively. 
Table 3

Mean, standard deviation, and p-value of the performance of groups $G V$ and $G X$ in the spelling assessment test

\begin{tabular}{|c|c|c|c|c|}
\hline Variable & Group & Mean & $S D$ & Significance $(p)$ \\
\hline \multirow[t]{2}{*}{ ELA } & V & 25.30 & 2.63 & \multirow{2}{*}{0.051} \\
\hline & $x$ & 21.90 & 8.27 & \\
\hline \multirow[t]{2}{*}{ DRLA } & V & 25.33 & 1.06 & \multirow{2}{*}{0.245} \\
\hline & $x$ & 24.30 & 3.79 & \\
\hline \multirow[t]{2}{*}{ DP } & V & 66.13 & 12.62 & \multirow{2}{*}{$<0.001 *$} \\
\hline & $x$ & 37.50 & 14.09 & \\
\hline \multirow[t]{2}{*}{ DPP } & V & 17.73 & 5.76 & \multirow{2}{*}{$<0.001 *$} \\
\hline & $x$ & 10.13 & 5.39 & \\
\hline \multirow[t]{2}{*}{ DF } & V & 32.73 & 3.89 & \multirow{2}{*}{$<0.001 *$} \\
\hline & $x$ & 23.50 & 5.23 & \\
\hline \multirow[t]{2}{*}{ DFR } & V & 59.03 & 7.23 & \multirow{2}{*}{$<0.001 *$} \\
\hline & $x$ & 46.27 & 14.28 & \\
\hline \multirow[t]{2}{*}{ EP } & V & 1.90 & 2.07 & \multirow{2}{*}{$<0.001 *$} \\
\hline & $x$ & 0.07 & 0.25 & \\
\hline \multirow[t]{2}{*}{ DS } & V & 25.47 & 3.76 & \multirow{2}{*}{$<0.001 *$} \\
\hline & $x$ & 17.57 & 6.45 & \\
\hline \multirow[t]{2}{*}{ MLO } & V & 24.33 & 3.75 & \multirow{2}{*}{$<0.001 *$} \\
\hline & $x$ & 17.27 & 4,87 & \\
\hline
\end{tabular}

Note: Numbers with an asterisk: statistically significant results. ELA: Alphabet Letter Writing (Escrita de Letras do Alfabeto); DRLA: Randomized Dictation of Alphabet Letters (Ditado Randomizado de Letras do Alfabeto); DP: Word Ditaction (Ditado de Palavras); DPP: Pseudoword Ditaction (Ditado de Pseudopalavras); DF: Ditaction With Picture Cards (Ditado com Figuras); DFR: Sentence Ditaction (Ditado de Frases); DS: Spelled Ditaction (Ditado Soletrado); MLO: Lexical Orthographic Retrieval (Escrita de Palavras por Memória Lexical Ortográfica); SD: Standard Deviation; GV: 5th Graders From Private School; GX: 5th Graders From Public School; Statistical Analysis: Mann-Whitney $U$ test.

In the public schools evaluated, there was a gradual increase in the mean values of correct answers for the groups GVI-GX in the majority of the tests administered, except for the tests alphabet letter writing (ELA) and pseudoword dictation (DPP), in which the mean value of correct answers of the group GVII was lower than that of the group GVI. In the test randomized dictation of alphabet letters (DRLA), the mean value of correct answers of the group GVIII was lower than that of the group GVII. Despite the higher grade level, the group GIX achieved higher performance than the group GVIII only in the tests randomized dictation of alphabet letters (DRLA), pseudoword dictation (DPP), and deliberate misspelling (EP).

Table 4 shows the correlations among pairs of variables, Spearman correlation coefficient, and level of significance $p$ for the performance of private school students in the groups GI-GV in the spelling assessment test.

As can be seen from Table 4, according to the Spearman correlation test, there was a statistically significant correlation between the variables in all versions of the test administered. As for the group GIII, the results indicated that the higher the performance in the test alphabet letter writing (ELA), the higher the performance in the test randomized dictation of alphabet letters (DRLA). The same result was found for the groups GI and GIV, which showed improvement in performance in the test dictation by spelling every letter in every word (DS). In the groups Gl, GII, GIII, and GIV, it was found that the higher the performance in the test dictation with picture cards (DF), the higher the performance in the test lexical orthographic retrieval (MLO). It was also observed that for all groups evaluated, the higher the performance in the test dictation by spelling every letter in every word (DS), the higher the performance in the test pseudoword dictation (DPP) and sentence dictation (DFR), and that the higher the performance in the test pseudoword dictation (DPP), the higher the performance in the test sentence dictation (DFR) and lexical orthographic retrieval (MLO).

Table 5 shows the correlations among pairs of variables, Spearman correlation coefficient, and level of significance $p$ for the performance of public school students in the groups GVI-GX in the spelling assessment test.

According to the Spearman correlation test, there was a statistically significant correlation between the variables in all versions of the test administered. In the groups GVII and GVIII, the results indicated that the higher the performance in the test written test alphabet letter writing (ELA), the higher the performance in the test dictation by spelling every letter in every word (DS). As for the groups GII, GIX, and GX, it was found that the higher the performance in the test randomized dictation of alphabet letters (DRLA), the higher 
the performance in the test dictation by spelling every letter in every word (DS). However, in the groups GVII and GIX, it was observed that the higher the performance in the test alphabet letter writing (ELA), the higher the performance in the test lexical orthographic retrieval (MLO). For all groups evaluated, it was found that the higher the performance in the test word dictation (DP), the higher the performance in the tests pseudoword dictation (DPP), sentence dictation (DFR), dictation with picture cards (DF), and lexical orthographic retrieval (MLO).

Table 4

Mean, standard deviation, and p-value of the performance of groups GIII and GVIII; and GIV and GIX in the spelling assessment test

\begin{tabular}{|c|c|c|c|c|c|c|c|c|c|c|}
\hline & & ELA & ELA & DRLA & DP & DP & DPP & DF & DFR & ELA \\
\hline \multirow[t]{2}{*}{ Group } & Statistical analysis & $x$ & $x$ & $x$ & $x$ & $x$ & $x$ & $x$ & $x$ & $x$ \\
\hline & & DRLA & DS & DS & DPP & DFR & DFR & MLO & MLO & MLO \\
\hline \multirow[t]{2}{*}{ । } & Correl. Coef. & 0.189 & 0.672 & 0.198 & 0.664 & 0.643 & 0.647 & 0.709 & 0.650 & 0.702 \\
\hline & Sig. & 0.318 & $<0.001 *$ & 0.294 & $<0.001 *$ & $<0.001 *$ & $<0.001 *$ & $<0.001$ * & $<0.001 *$ & $<0.001$ * \\
\hline \multirow[t]{2}{*}{ II } & Correl. Coef. & 0.182 & -0.155 & 0.093 & 0.558 & 0.742 & 0.717 & 0.537 & 0.584 & 0.189 \\
\hline & Sig. & 0.335 & 0.412 & 0.625 & $0.001 *$ & $<0.001 *$ & $<0.001 *$ & $0.002 *$ & $0.001 *$ & 0.317 \\
\hline \multirow[t]{2}{*}{ III } & Correl. Coef. & 0.454 & 0.196 & 0.164 & 0.529 & 0.778 & 0.479 & 0.552 & 0.499 & 0.192 \\
\hline & Sig. & $0.012 *$ & 0.300 & 0.386 & $0.003 *$ & $<0.001 *$ & $0.007 *$ & $0.002^{*}$ & $0.005^{*}$ & 0.309 \\
\hline \multirow[t]{2}{*}{ IV } & Correl. Coef. & 0.184 & 0.433 & 0.219 & 0.610 & 0.796 & 0.615 & 0.659 & 0.528 & 0.095 \\
\hline & Sig. & 0.331 & $0.017 *$ & 0.245 & $<0.001 *$ & $<0.001 *$ & $<0.001 *$ & $<0.001 *$ & $0.003 *$ & 0.619 \\
\hline \multirow[t]{2}{*}{ V } & Correl. Coef. & 0.155 & 0.311 & 0.087 & 0.664 & 0.805 & 0.657 & 0.349 & 0.608 & 0.391 \\
\hline & Sig. & 0.413 & 0.095 & 0.649 & $<0.001 *$ & $<0.001 *$ & $<0.001 *$ & 0.059 & $<0.001 *$ & $0.033^{*}$ \\
\hline
\end{tabular}

Note: Numbers with an asterisk: statistically significant results.

ELA: Alphabet Letter Writing (Escrita de Letras do Alfabeto); DRLA: Randomized Dictation of Alphabet Letters (Ditado Randomizado de Letras do Alfabeto); DP: Word Ditaction (Ditado de Palavras); DPP: Pseudoword Ditaction (Ditado de Pseudopalavras); DF: Ditaction With Picture Cards (Ditado com Figuras); DRF: Sentence Ditaction (Ditado de Frases); DS: Spelled Ditaction (Ditado Soletrado); MLO: Lexical Orthographic Retrieval (Escrita de Palavras por Memória Lexical Ortográfica); Gl: 1st graders from private school; GII: 2nd graders from private school; GIII: 3rd graders from private school; GIV: 4th graders from private school; GV: 5th graders from private school; Statistical Analysis: Spearman correlation test. Correl. Coef: Correlation coeficiente; Sig.: Significance.

Table 5

Correlations among pairs of variables, Spearman correlation coefficient, and level of significance p for the performance of public school students in the spelling assessment test

\begin{tabular}{|c|c|c|c|c|c|c|c|c|c|c|}
\hline & & ELA & ELA & DRLA & DP & DP & DPP & DF & DFR & ELA \\
\hline \multirow[t]{2}{*}{ Group } & Statistical analysis & $x$ & $x$ & $x$ & $x$ & $x$ & $x$ & $x$ & $x$ & $x$ \\
\hline & & DRLA & DS & DS & DPP & DFR & DFR & MLO & MLO & MLO \\
\hline \multirow[t]{2}{*}{$\mathrm{VI}$} & Correl. Coef. & 0.122 & -0.138 & 0.258 & 0.806 & 0.785 & 0.543 & 0.775 & 0.760 & 0.092 \\
\hline & Sig. & 0.527 & 0.474 & 0.177 & $<0.001 *$ & $<0.001 *$ & $0.002 *$ & $<0.001 *$ & $<0.001 *$ & 0.635 \\
\hline \multirow[t]{2}{*}{ VII } & Correl. Coef. & 0.356 & 0.520 & 0.498 & 0.914 & 0.926 & 0.873 & 0.852 & 0.861 & 0.507 \\
\hline & Sig. & 0.054 & $0.003 *$ & $0.005^{*}$ & $<0.001 *$ & $<0.001^{*}$ & $<0.001^{*}$ & $<0.001^{*}$ & $<0.001 *$ & $0.004 *$ \\
\hline \multirow[t]{2}{*}{ VIII } & Correl. Coef. & 0.039 & 0.429 & 0.149 & 0.673 & 0.841 & 0.646 & 0.697 & 0.799 & 0.552 \\
\hline & Sig. & 0.837 & $0.018^{*}$ & 0.432 & $<0.001 *$ & $<0.001 *$ & $<0.001 *$ & $<0.001^{*}$ & $<0.001 *$ & 0.002 * \\
\hline \multirow[t]{2}{*}{ IX } & Correl. Coef. & 0.352 & 0.134 & 0.389 & 0.605 & 0.954 & 0.565 & 0.742 & 0.870 & 0.246 \\
\hline & Sig. & 0.057 & 0.480 & $0.034 *$ & $<0.001 *$ & $<0.001 *$ & $0.001 *$ & $<0.001 *$ & $<0.001 *$ & 0.191 \\
\hline \multirow[t]{2}{*}{$x$} & Correl. Coef. & 0.260 & 0.259 & 0.622 & 0.662 & 0.838 & 0.707 & 0.536 & 0.643 & 0.200 \\
\hline & Sig. & 0.165 & 0.168 & $<0.001 *$ & $<0.001 *$ & $<0.001 *$ & $<0.001 *$ & $0.002 *$ & $<0.001 *$ & 0.289 \\
\hline
\end{tabular}

Note: Numbers with an asterisk: statistically significant results.

ELA: Alphabet Letter Writing (Escrita de Letras do Alfabeto); DRLA: Randomized Dictation of Alphabet Letters (Ditado Randomizado de Letras do Alfabeto); DP: Word Ditaction (Ditado de Palavras); DPP: Pseudoword Ditaction (Ditado de Pseudopalavras); DF: Ditaction With Picture Cards (Ditado com Figuras); DRF: Sentence Ditaction (Ditado de Frases); DS: Spelled Ditaction (Ditado Soletrado); MLO: Lexical Orthographic Retrieval (Escrita de Palavras por Memória Lexical Ortográfica); Gl: 1st graders from private school; GII: 2nd graders from private school; GIII: 3rd graders from private school; GIV: 4th graders from private school; GV: 5th graders from private school; Statistical Analysis: Spearman correlation test. Correl. Coef: Correlation coeficiente; Sig.: Significance. 


\section{Discussion}

The results of this study showed that the 1st graders from both private and public schools demonstrated similar knowledge of spelling and rules of the Brazilian Portuguese language. These results are expected since the groups assessed were at the beginning of literacy and spelling acquisition. Due to their age and grade level, the students had had little reading experience and even less writing experience, which led to a restricted access to orthographic lexicon pathway (Affonso, Piza, Barbosa, \& Macedo, 2010; Arnaut, Hackerott, Bueno, Nepomuceno, \& Ávila, 2014).

The data of the 2 nd-5th grades demonstrated that private school students achieved significantly higher overall performance than public school students in all versions of the test administered, except for the ELA and DRLA tests. These results corroborate those of international studies (MalloyDiniz et al., 2008; Pagliuso \& Pasian, 2007), which compared the performance of neuropsycholinguistic profiles of children and adolescents, and a national study conducted by Arnaut et al. (2014), who compared the performance of public and private school students in a syntagma dictation test. All of these studies reported that private school students attained higher performance.

The results obtained in the present study showed that the performance of both private and public school students in higher grade levels improved in most of the collective and individual versions of the spelling test administered, indicating that the knowledge of spelling rules increased across grades. These findings corroborate those of other studies that have similarly reported that there are more spelling errors at the earlier stages of spelling development than those in higher grade levels (Affonso et al., 2010; Bartholomeu, Sisto, \& Rueda, 2006; Capellini et al., 2011; Dias \& Ávila, 2008; Santos, 2009; Suehiro \& Hohlenwerger, 2014; Rosa, Gomes, \& Pedroso, 2012).

However, in the present study, it was found that 3rd and 4th graders from both private and public schools demonstrated similar knowledge of spelling and rules of the Brazilian Portuguese language. Such knowledge was higher than that of 1st and 2nd graders in most tests administered thus showing that from 3rd grade onwards there may have been a greater emphasis on the teaching of spelling and grammar rules, leading to these performance results in the comparison between the groups evaluated. These results show the influence of the learning process and acquisition of literacy on the development of writing (Gindri et al., 2005; Queiroga, Lins, \& Pereira, 2006).

These results can be explained by the fact learning to spell is a developmental and progressive process, in which students formulate hypotheses about writing concepts demonstrating the different levels of the knowledge being acquired. This means that writing development is not an immediate process, and that making mistakes is part of the process (Capellini et al., 2011; Santos \& Befi-Lopes, 2013; Zorzi \& Ciasca, 2008).

The correlated data showed that for both private and public school students, the higher the performance in the test lexical orthographic retrieval, the higher the performance in the tests word dictation, dictation with picture cards, and sentence dictation due to the quicker access to phonological and lexical information to correctly written words. These data corroborate those of other studies that found that the greater the exposure to reading and writing, the greater the number of words stored in the mental lexicon, preventing spelling mistakes (Capellini \& Lanza, 2010; Savage et al., 2005).

Although the results of the tests word dictation, pseudoword dictation, and sentence dictation were positively correlated, the mean value of correct answers of the tests word dictation and sentence dictation were higher than those of the test pseudoword dictation, for both private and public school students. These data corroborate those of other studies that reported a higher performance in the writing of regular high-frequency words than that of low- frequency words and invented words, 
demonstrating that the greater the perceptual, auditory and visual exposure to words, the more familiar these words become to children (Capellini \& Lanza, 2010; McQuiston, O'Shea, \& McCollin, 2008; Santos \& Befi-Lopes, 2013). Nevertheless, the low mean values of correct answers obtained in the test pseudoword dictation compared to those of the word dictation and sentence dictation tests in the present study indicate the need for formal systematic instruction of spelling promoting and encouraging reading in schools (Pinheiro, Lúcio, \& Silva, 2008).

The results of the present study well demonstrated the normal orthographic processing in private and public school students. However, based on the findings and on literature reports, it can be said that at the beginning of literacy acquisition, many students may have difficulties with spelling since most schools do not focus on the spelling and writing instruction due to the inadequate theoretical and practical training of their teachers (Capellini et al., 2011; Rosa et al., 2012; Santos \& Barrera, 2012).

Such fact can be confirmed by the results of the test deliberate misspelling (EP), since, regardless of the type of school, the results were statistically significant, and the mean values of correct answers were very low, indicating that the students have little orthographic knowledge. Considering that this is a test in which the students are asked to intentionally misspell words and one point was given only for properly justified mistake, the results obtained show their limited orthographic knowledge.

Santos and Barrera (2012) showed that there is a directly proportional relationship between spelling performance and intentional misspelling task results. Their findings, as well as those obtained in the present study, indicate that spelling development is a complex process and its success cannot be attributed only to the correct words learned from reading and that it can be spontaneously acquired through the interaction with the written language. Therefore, students must develop metalinguistic skills based on phonological, morphosyntactic, and contextual knowledge.

Corroborating the aforementioned authors, Moraes (2008) argued that the teaching of spelling should be systematic and should make students consider and reflect on its concepts. Therefore, it can be said that for an effective spelling acquisition, in both public and private schools, students should be closely guided throughout the process, promoting active learning and inducing them to think and consider possible spellings until it becomes automatic. Teachers should always focus on the spelling rules of the Brazilian Portuguese enabling students to become good spellers and writers.

As for the hypothesis of the present study, considering only the mean values obtained in the tests administered, private school students achieved higher performance than public school students, showing that although the rules of encoding words are not explicitly taught in these types of schools, private schools give more emphasis to the teaching of spelling than do public schools. However, it is worth mentioning that with regard to the test about explicit spelling knowledge (deliberate misspelling test), both private and public school students had similar but low mean values of correct answers, indicating that regardless of the type of education, the students evaluated demonstrated orthographic processing deficit.

\section{Conclusion}

The results obtained showed that the mean values of correct answers in all versions of the spelling test administered increased across grades for both private and public school students.

Based on these results, it can also be concluded that private school students achieved higher performance than public school students from the 2 nd grade onwards, except for the test deliberate misspelling, in which students from both types of school had similar performance. 
Given the scarcity of studies on this topic, one of the limitations of the present study is the lack of in-depth comparisons of the results obtained. Therefore, further investigations are needed to extend current knowledge of spelling performance and contribute to the work of education and health professionals.

\section{Contributors}

All authors contributed to the conception and design of the study, data analysis and final editing.

\section{References}

Affonso, M. J. C. O., Piza, C. M. J. T., Barbosa, A. C. C., \& Macedo, E. C. (2010). Avaliação de escrita na dislexia do desenvolvimento: tipos de erros ortográficos em prova de nomeação de figuras por escrita. Revista Cefac, 13(4), 628-635. Recuperado em março 4, 2014, de http://tede.mackenzie.com.br//tde_busca/arquivo. php? codArquivo $=1880$

Arnaut, M. A., Hackerott, M. M. S., Bueno, G. J., Nepomuceno, P. F., \& Ávila, C. R. B. (2014). Erros de base fonológica na escrita: codificação de surdas e sonoras, segmentação e juntura vocabular. Audiology - Communication Research, 19(3), 264-271. https://doi. org/10.1590/S2317-643120140003000010

Bartholomeu, D., Sisto, F. F., \& Rueda, F. J. M. (2006). Dificuldades de aprendizagem na escrita e características emocionais de crianças. Psicologia e Estudo, 11(1), 139-146. https://doi.org/10.1590/S141373722006000100016

Batista, A. O., Cervera-Mérida, J. F., Ygual-Fernández, A., \& Capellini, S. A. (2014). Pró-ortografia: protocolo de avaliação da ortografia para escolares do segundo ao quinto ano do ensino fundamental. Barueri: Pró-Fono.

Capellini, S. A., \& Lanza, S. C. (2010). Desempenho de escolares em consciência fonológica, nomeação rápida, leitura e escrita. Pró-Fono Revista de Atualização Científica, 22(3), 239-244. https://doi.org/10.1590/ S0104-56872010000300014

Capellini, S. A., Amaral, A. C., Oliveira, A. B., Sampaio, M. N., Fusco, N., Cervera-Mérida, J. F., \& Ygual-Fernández, A. (2011). Desempenho ortográfico de escolares do $2^{\circ}$ ao $5^{\circ}$ ano do ensino público. Jornal da Sociedade Brasileira de Fonoaudiologia, 23(3), 227-236. https:// doi.org/10.1590/S2179-64912011000300008

Cervéra-Mérida, J. F., \& Ygual-Fernández, A. (2006). Uma propuesta de intervención em trastornos disortográficos atendiendo a la semiologia de los errores. Revista Neurology, 42(2), 117-126.

Dias, R. S., \& Ávila, C. R. B. (2008). Uso e conhecimento ortográfico no transtorno específico da leitura. Revista da Sociedade Brasileira de Fonoaudiologia, 13(4), 381-390. https://doi.org/10.1590/S1516-80342008000400014

Gindri, G., Keske-Soares, M., \& Mota, H. B. (2005). Memória de trabalho, consciência fonológica e hipótese de escrita. Pró-Fono Revista de Atualização Científica, 17(2), 195-200. https://doi.org/10.1590/S010456872007000300010

Guimarães, S. R. K., Paula, F. V., Mota, M. M. P. E., \& Barbosa, V. R. (2014). Consciência morfológica: que papel exerce no desempenho ortográfico e na compreensão de leitura? Psicologia USP, 25(2), 201-212. https://doi.org/10.1590/0103-6564A20133713

Kleiman, A. (2001). Leitura: ensino e pesquisa. Campinas: Pontes.

Lima, T. C. F., \& Pessoa, A. C. R. G. (2007). Dificuldades de aprendizagem: principais abordagens terapêuticas discutidas em artigos publicados nas principais revistas indexadas no LILACS de fonoaudiologia no período de 2001 a 2005. Revista Cefac, 9(4), 469-476. https://doi. org/10.1590/\$1516-18462007000400006

Malloy-Diniz, L. F., Wellington, B. L., Moraes, P. H. P., Correa, H., Bechara, A., \& Fuentes, D. (2008). Versão em português do lowa Gambling Test: adaptação transcultural e validade discriminante. Revista Brasileira de Psiquiatria, 30(6), 144-148.

Manzano, J. L. G., Sanz, M. T., \& Chocano, A. J. D. (2008). Fundamentos para la intervención en el aprendizaje de la ortografia. Espanha: Editorial Cepe.

Mcquiston, K., O'shea, D., \& Mccollin, M. (2008). Improving phonological awareness and decoding skills of high schools students from diverse backgrounds. Previous School Failure, 52(2), 67-70. https://doi.org/10.3200/ PSFL.52.2.67-72

Moraes, A. G. (2008). Ortografia: ensinar e aprender. São Paulo: Ática.

Mousinho, R., \& Correa, J. (2009). Habilidades lingüísticocognitivas em leitores e não-leitores. Pró-Fono Revista de Atualização Científica, 21(2), 113-118. https://doi. org/10.1590/S0104-56872009000200005

Pagliuso, L., \& Pasian, S. R. (2007). As figuras complexas de Rey: normas preliminares com crianças de 9 e 10 anos. Psico, 38(2), 148-156. Recuperado em março 4, 2014, de http://dialnet.unirioja.es/servlet/ oaiart?codigo $=5161376$

Paschoal, L., Pezarini, I. O., Vaz, S., \& Chacon, L. (2014). Characteristics of fricatives consonants orthography in Brazilian children. Audiology-Communication Research, 19(4), 333-337. 
Pinheiro, A. M. V., Lúcio, P. S., \& Silva, D. R. (2008). Avaliação cognitiva de leitura: o efeito de regularidade grafema-fonema e fonema-grafema na leitura em voz alta de palavras isoladas no português do Brasil. Psicologia, Teoria e Prática, 10(2), 16-30. Recuperado em março 12, 2014, de https://doaj.org/ article/02372571ca8a4f03a3bbd7b4a3b5fe45

Queiroga, B. A., Lins, M. B., \& Pereira, M. A. (2006). Conhecimento morfossintático e ortografia em crianças do ensino fundamental. Psicologia: Teoria e Pesquisa, 22(1), 95-99. https://doi.org/10.1590/S010237722006000100012

Rosa, C. C., Gomes, E., \& Pedroso, F. S. (2012). Aquisição do sistema ortográfico: desempenho na expressão escrita e classificaçã̃o dos erros ortográficos. Revista CEFAC, 14(1), 39-45. Recuperado em abril 2, 2014, de https://doaj.org/ article/60165e49fb494618b697daf090ec785f

Salles, J. F., Parente, M. A. M. P., \& Freitas, L. B. L. (2010). Leitura/escrita de crianças: comparações entre grupos de diferentes escolas públicas. Paidéia, 20(4), 335-344. https://doi.org/10.1590/S0103-863X2010000300006

Santos, M. J., \& Barrera, S. D. (2012). Relação entre conhecimento explícito da ortografia e desempenho ortográfico. Psicologia Escolar e Educacional, 16(2), 257-263.

Santos, M. T. M. (2009). Dislexia: princípios para a intervenção fonoaudiológica. In T. Barbosa, C. C. Rodrigues, C. B.
Mello, S. A. Capellini, R. Mousinho, \& L. M. Alves (Eds.), Temas em dislexia (pp.49-54). São Paulo: Artes Médicas.

Santos, M. T. M., \& Befi-Lopes, D. M. (2013). Análise da ortografia de alunos do $4^{\circ}$ ano do ensino fundamental a partir de ditado de palavras. CoDAS, 25(3), 256-261.

Savage, R. S., Frederickson, N., Goodwin, R., Patni, U., Smith, N., \& Tuersley, L. (2005). Relationship among rapid digit naming, phonological processing, motor automaticity, and speech perception in poor, average, and good readers and spellers. Journal Learning Disability, 38(1), 92-98. https://doi.org/10.1177/00222194050380010201

Smythe, L., Everatt, J., Al-Menaye, N., He, X., Capellini, S. A., Gyarmathy, E., \& Siegel, L. (2008). Predictors of word-level literacy amongst grade 3 children in five diverse languages. Dyslexia, 14(3), 170-187. https://doi. org/10.1002/dys.369

Suehiro, A. C. B., \& Hohlenwerger, V. L. (2014). Escrita em grupo de escolares. Avaliação Psicológica, 13(3), 391-398.

Zorzi, J. L., \& Ciasca, S. M. (2008). Caracterização dos erros ortográficos em crianças com transtornos de aprendizagem. Revista CEFAC, 10(3), 321-333. https:// doi.org/10.1590/S1516-18462008000300007

Received: November 3, 2014

Final version: October 16, 2015

Approved: December 3, 2015 